\title{
UPAYA PENINGKATAN KESEJAHTERAAN KELUARGA MELALUI BUDIDAYA RUMPUT LAUT (Studi Di Desa Kolese Kecamatan Pasikolaga Kabupaten Muna)
}

\author{
La Ode Muhamad Ghalib ${ }^{1}$, Sarmadan ${ }^{2}$, Tanzil ${ }^{3}$
}

${ }^{123}$ Universitas Halu Oleo

Email: barisalaghalib@gmail.com, sarmadan@uho.ac.id, tanzilsosio@gmail.com

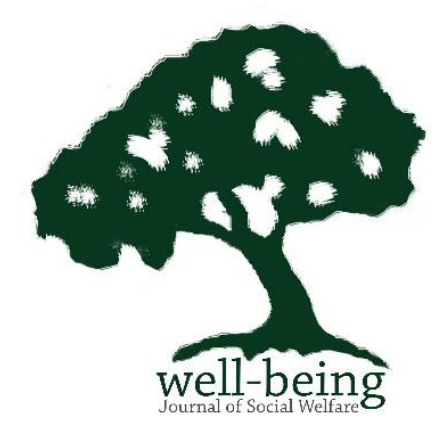

ABSTRAK

\begin{abstract}
This study aims to analyze how the efforts to improve family welfare through seaweed cultivation in college villages. This type of research is qualitative descriptive research. Data collection techniques were carried out by means of observation, interviews and documentation with 8 research informants in the community of Kolese Village, Pasikolaga District.

The results of this study are efforts to improve family welfare through seaweed cultivation, namely increasing economic income by fulfilling family needs and being able to pay for children's schooling. With the existence of a joint business group, it is one of the efforts that can improve family welfare. The results achieved by the people of Kolese Village, Pasikolaga District, Muna Regency in an effort to increase welfare welfare through seaweed cultivation have been overcome by cultivating seaweed.
\end{abstract}

Keywords: Effort, Improvement, Welfare, Family, Cultivation

\section{PENDAHULUAN}

Indonesia merupakan negara dengan sumber daya alam (SDA) yang melimpah namun akses dan kontrolnya masih didominasi oleh sedikit orang, sementara puluhan juta lainnya terpinggirkan, hidup dalam ketiadaan dan menjadi fakir miskin. Menurut data BPS tahun 2010, sebesar 37,17 juta (sekitar $16,58 \%$ ) penduduk Indonesia tergolong miskin atau berpenghasilan rendah. Sebagian dari mereka adalah pelaku usaha mikro yang punya keterbatasan akses terhadap sumber daya, terutama sumber daya ekonomi dan pasar. Keluarga miskin kebanyakan menggeluti kegiatan ekonomi rumah tangga dan sektor informal yang rentan dan paling mudah terkena dampak jika terjadi krisis ekonomi. (Adnan,2012).

Masalah kemiskinan merupakan masalah yang hampir di alami semua negara. Namun Indonesia khususnya, kemiskinana masih banyak di alami masyarakat, baik masyarakat pedesaan maupun perkotaan. Secara luas miskin di artikan sebagai ketidak mampuan seseorang dalam memenuhi kebutuhannya dimana kebutuhan disini di artikan secara relatif sesuai dengan persepsi dirinya. Kebutuhan yang tidak dapat di penuhi tersebut mencakup berbagai aspek baik kebutuhan ekonomi, sosial, politik, emosional maupun spiritual. Beberapa ciri masyarakat miskin di tinjau dari berbagai aspek salah satunya aspek ekonomi yaituh rendahnya kualitas SDM, termaksud kesehatan, pendidikan dan keterampilan yang berdampak pada rendahnya penghasilan. (Hanif, 2011). Untuk mencapai hidup sejahtera dan berkualitas, dibutuhkan suatu upaya penyadaran dan pemberian kekuatan untuk dapat melakukan perubahan kearah yang lebih baik. Kesejahteraan sosial pada masyarakat di awali pada unit terkecil, yaitu kesejahteraan pada keluarga, keluarga sangat penting posisinya dalam kehidupan masyarakat, karena keluarga adalah lingkungan pertama bersosialisasi dalam hidup seseorang. Kesejahteraan keluarga meliputi kesejahteraan sandang, pangan dan papan yang merupakan suatu kewajiban utama yang harus dicukupi 
dalam kehidupan sehari-hari (Aliyudin, 2009).

Prioritas utama dalam kesejahteraan sosial adalah kelompokkelompok kurang beruntung, khususnya keluarga miskin, dimana dalam kesejahteraan sosial ini, dilakukan berbagai upaya untuk meningkatakan kualitas hidupnya. Upaya tersebut dilakukan melalui pemberdayaan. Pemerintah menyediakan layanan program pemberdayaan baik untuk masyarakat luas maupun kelompok masyarakat tertentu, karena pemberdayaan tidak dapat terlepas dari partisipasi masyarakat (Aliyudin,2009).

Desa Kolese Kecamatan Pasikolaga Kabupaten Muna memiliki potensi lokal yakni luasnya sumber daya alam dan cukup melimpahnya air yang dapat digunakan untuk Budi daya Rumput Laut. Awalnya masyarakat hanya memanfaatkan lahan tersebut untuk kegiatan pertanian saja dimana sangat bergantung padacuaca atau musiman sehingga hasil yang didapat tidak menentu. Masyarakat belum memaksimalkan pemanfaatan sumber daya alam di lingkungan sekitar untuk lebih meningkatkan kesejahteraan mereka. Hal ini disebabkan karena masyarakat memiliki keterbatasan pengetahuan dan keterampilan mengolah potensi alam khususnya dalam bidang budidaya rumput laut.

Program kelompok usaha bersama yang dilakukan oleh pemerintah Desa Kolese dibawah naungan Dinas Perikanan dan masyarakat Desa Kolese cukup gencar sehingga membentuk suatu kelompok binaan pembudidaya rumput laut. Budidaya rumput laut merupakan usaha pemberdayaan masyarakat yang diterapkan untuk meningkatkan kesejahteraan masyarakat desa Kolese. Pada awal mulanya, di Desa ini hanya ada beberapa yang mengembangkan usaha perikanan. Masyarakat dengan jenis profesi yang beragam dan masih ada masyarakat yang menganggur. Akan tetapi, sebagian masyarakat mempunyai kesadaran untuk melakukan usaha meningkatkan pendapatan melalui pemanfaatan sumber daya disekitar. Budidaya rumput laut dirasa tepat sebagai suatu usaha pemberdayaan masyarakat Desa Kolese karena sesuai dengan potensi lokal yang ada. Budidaya rumput laut juga bisa menjadi referensi daerah lain agar bisa mengembangkan potensi lokal yang ada. Budidaya rumput laut juga menjadi wadah bagi anggota dan masyarakat dalam belajar bersama kaitannya dalam peningkatan pengetahuan dan keterampilan budidaya rumput laut yang benar.

Melihat kondisi seperti yang disebutkan, pemberdayaan sangat penting dilakukan agar masyarakat di Desa Kolese lebih berdaya, guna dan dapat memanfaatkan potensinya dalam mengelola sumber daya yang ada untuk mencapai kehidupan yang lebih sejahtera dalam Peningkatan kesejahteraan keluarga dari segi ekonomi, pendidikan, kesehatan serta kehidupan sosial pada masyarakat desa Kolese.Untuk melihat potensi masyarakat desa kolese yang mampu membudidayakan rumput laut maka saya sebagai mahasiswa mengangkat judul proposal yaitu Upaya Peningkatan Kesejahteraan Keluarga Melalui Budidaya Rumput Laut (Studi Di Desa Kolese Kecamatan Pasikolaga Kabupaten Muna) Tahun 2019-2020.

\section{METODE PENELITIAN}

Jenis penelitian ini adalah menggunakan jenis penelitian kualitatif. untuk menghasilkan data deskriptif berupa ucapan, tulisan dan perilaku yang dapat diamati dari orang tua atau subjek tertentu secara detail. Informan dalam penelitian ini adalah masyarakat desa kolese, Kecamatan Pasikolaga yang berjumlah 8 orang. Adapun pemilihan informan dilakukan dengan penunjukan langsung kepada 
subjek yang dianggap memiliki pengetahuan tentang permasalahan yang akan diteliti yaituh upaya peningkatan kesejahteraan keluarga melalui budidaya rumput laut (studi di desa kolese, kecamatan pasikolaga, kabupaten muna) tahun 2019/2020. sumber data yang di gunakan dalam penelitian ini adalah data primer yang diperoleh dari masyarakat pesisir desa Kolese dan data sekunder berupa informasi untuk menunjang kematangan penelitian, seperti hasil penelitian, buku, jurnal, dan artikel yang relevan dengan penelitian ini.

\section{HASIL DAN PEMBAHASAN}

\section{Upaya Peningkatan kesejahteraan keluargaMelalui Budidaya Rumpt Laut Di Desa Kolese}

Teori Usman Yatim dan Enny A Hendargo menyatakan bahwa upaya upaya dalam meningkatkan ekonomi kesejahteraan keluarga yaituh dengan cara sebagai berikut: Pertama, adanya modal yakni membantu untuk memberikan bantuan dalam membangun produksi usaha bagi orang yang tidak mampu ekonominya. Kedua, memiliki keterampilan yakni membantu untuk seseorang dalam menentukan usaha produksinya. Ketiga, menguasai teknologi yakni membantu seseorang untuk mempermudah produksi usaha maupun pemasaran. Keempat, Memiliki lahan usaha yakni untuk mendirikan suatu usaha yang akan di jalani (Usman,1992).

\section{a. proses usaha produksi rumput laut.}

Sesuai dengan teori Kartasasmita dalam Zubaedi mengatakan bahwa memperkuat potensi atau daya yang dimiliki oleh masyarakat. Upaya ini berupa pemberdayaan yang menyangkut pembangunan prasarana dan sarana dasar fisik serta ketersediaan program dari pemerintah berupa pendanaan, pelatihan, dan pemasaran di pedesaan, untuk produksi rumput laut, mulai dari konsentrasi penduduk yang keberdayaannya kurang. Di sini strategi yang dilakukan sudah efektif, yaitu masyarakat memanfaatkan dan mendapatkan prasarana dan sarana melalui kelompok dalam pemberdayaan rumput laut dan para kelompok petani rumput laut memperoleh pendanaan dari pemerintah tiap kelompok.

Upaya masyarakat Desa Kolese Kecamatan Pasikolaga dalam meningkatkan kesejahteraan keluarga melalui budidaya rumput laut menghasilkan banyak manfaat di desa Kolese kecamatan Pasikolaga, adapun awal mula dan upaya masyarakat desa Kolese kecamatan Pasikolaga melalui budidaya rumput laut berdasarkan hasil wawancara dengan bapak La Kaji secara keseluruhan sebagai berikut:

1. Proses usaha Produksi dan awal mula Budidaya Rumput Laut yang dilakukan oleh masyarakat Desa Kolese Kecamatan Pasikolaga.

2. Motivasi kepada masyarakat melalui budidaya rumput laut untuk membiayai anaknya dalam bidang pendidikan Melalui budidaya rumput laut baik dari pengelola maupun petani rumput laut merasakan manfaatnya yaituh perubahan dalam peningkatan kesejahteraan keluarga. Dari hasil panen tersebut tidak jarang mengalami gagal panen yang di sebabkan hama sehingga meyebabkan hasil panen berkurang danpenghasilan juga menyurut. Dengan adanya kelompok usaha bersama melalui budidaya rumput laut sangat memberikan manfaat kepada masyarakat desa kolese dalam peningkatan kesejahteraan keluarga. Indikator keberhasilan dalam peningkatan kesejahteraan dengan adanya pemberdayaan masyarakat melalui usah budidaya rumput laut cukup membantu mencukupi kebutuhan keluarga dan pembiayaan sekolah. Dalam upaya meningkatkan produktivitas sumber daya 
manusia dan sumber daya alam tidak hanya sebatas teori melainkan memberdayakan masyarakat agar menjadi kreatif dan terampil untuk mencukupi hidupnya. Maksud dari kreatif dan terampil disini adalah dalam mendesain pola, sehingga

\section{b. Melalui Kelompok Usaha Bersama}

Kelompok Usaha Bersama (KUBE) merupakan salah satu media pemberdayaan yang diciptakan untuk membangun kemampuan warga masyarakat keluarga miskin dalam memecahkan masalah, memenuhi kebutuhan dan mengembangkan potensi guna meningkatkan kesejahteraan sosialnya. Dimensi sosial dan ekonomi menjadi pilar inti dari kegiatan KUBE. Secara sosial, KUBE menjadi wadah bergabungnya warga masyarakat keluarga miskin, sehingga memungkinkan mereka melakukan interaksi sosial yang positif dan demokratis. Melalui KUBE warga masyarakat keluarga miskin dapat meningaktkan kemampuan berkomunikasi, menyelesaikan masalah-masalah personal dan kelompok secara timbal balik, yang pada akhirnya memikat dan martabat kemanusiaan mereka. Secara ekonomi, kegiatan usaha yang dilakukan dalam kelompok, member kekuatan untuk menghimpun kekuatan modal, kemampuan bersaing, membangun jejaring, membuka peluang mengakses. Pada kasus yang tidak dimasukkan, mungkin ada sedikit hubungan opersional antara bagian bisnis atau bisnis yang hampir seluruhnya terserap dalam organisasi induk. Kelompok usaha bersama dari perusahaan yang secara legal independen tetapi dengan tingkatan kepemilikan yang beragam, Perbedaan pertama yang paling menonjol adalah tidak adanya pimpinan yang memerintah dan tidak ada gaji pada akhir minggu. Hal ini terasa menggembirakan bagi sebagian orang namun bisa juga menakutkan (Andi,2015)

\section{c. Peningkatan Penghasilan}

Peningkatan penghasilan dapat dijelaskan sebagai suatu upaya yang dilakukan untuk membantu mengatasi keluarga miskin pada dasarnya sering menggunakan pendekatan ekonomi, antara lain memberikan bantuan modal kepada keluarga miskin, pemberian bantuan modal selama ini tidak diikuti oleh adanya pengembangan kapasitas dari keluarga miskin. Keberadaan kelompok pada dasarnya sangat potensial untuk dikembangkan dan dikelola. Pengembangan dan kelompok tersebut. Melalui pendekatan kelompok, pada dasarnya didalamnya terdapat pemberdayaan dan kemandirian anggota kelompok sesuai dengan substansi yang ada dalam disiplin penyuluhan. Kemudian masyarakat dapat memproduksi dan menjual produknya sehingga dapat meningkatkan pendapatan mereka. Pendapatan yang mereka dapatkan juga dapat meningkatkan kesejahteraan ekonomi mereka (Kartasasmita,1996).

Hasil yang di capai oleh masyarakat desa kolese dalam upaya peningkatan kesejahteraan keluarga melalui budidaya rumput laut dapat teratasi, dengan membudidayakan rumput laut, dimana hasil jual yang cukup besar, sehingga membantu beban ekonomi keluarga dan menjadikan keluarga menjadi sejahtera.

Hasil yang di capai adanya nilai panen budidaya rumput laut dengan beberapa unsur yaituh:

1. Rumput laut yang di kelolah secara baik dan benar dapat memberikan nilai pendapatan yang tinggi sehingga dapat membantu beban kehidupan ekonomi keluarga.

2. Nilai jual yang tinggi dari hasil rumput laut, dapat di kelolah secara baik dan benar keuanganya,

3. Dari hasil budidaya rumput laut, tentunya di manfaatkan sedemikian rupa untuk mengelolah keuangan keluarga 
sehingga bukan menjadi beban ekonomi dalam keluarga dan membuat keluarga lebih sejahtera dengan hasil pendapatan yang ada.

Keadaan demikian membuat membuat masyarakat merasa nyaman dengan membudidayakan rumput laut karena nilai jual yang tinggi akan jelas sangat membantu beban perekonomian keluarga, sehingga keluarga akan lebih sejahtera dalam kehidupan sehari-hari.

Pernyatan salah satu informan yang menyatakan bahwa usaha budidaya rumput laut bisa mencukupi kehidupan sehari-hari dan bisa untuk mencukupi kebutuhan lainnya.

"Alhamdulilah yah cukup mencukupi, dan bisa sedikit demi sedikit membangun rumah mungkin seperti itu"(wawancara dengan bapak La Harfa 15 Agustus 2020). Pernyataan Informan di dukung dengan pernyataan informan lain yang menjelaskan hasil budidaya rumput laut dapat untuk meyekolahkan anak-anaknya. Berikut peryataannya:

Oleh karena itu budidaya rumput laut telah dapat memberdayakan masyarakat Desa Kolse Kecamatan Pasikolaga yang juga dapat membatu ekonomi keluarga dan nilai pendapatan keluarga lebih meningkat. Adanya pemberdayaan rumput laut ini menjadikan proses dengan mana orang menjadi cukup kuat untuk berpartisipasi dalam, berbagi pengontrolan atas, dan mempengaruhi terhadap kehidupan dan keluarganya memperoleh keterampilan, pengetahuan, dan kekuasaan yang cukup untuk mempengaruhi kehidupannya dan kehidupan orang lain yang menjadi perhatiannya.

\section{KESIMPULAN}

Berdasarkan hasil penelitian dan pembahaan yang di lakukan tentang upaya masyarakat melalui usaha budidaya rumput laut terhadap peningkatan kesejahteraan keluarga maka dapat di simpulkana sebagai berikut:
1. Upaya dalam peningkatan kesejahteraan keluarga melalui usaha budidaya rumput laut yaitu menambah pendapatan ekonomi dengan mencukupi kebutuhan keluarga dan mampu membiayai sekolah anaknya. Dengan adanya budidaya rumput laut memotivasi masyarakat untuk berpikir kearah yang lebih maju selain itu juga merubah gaya hidupnya.

2. Dengan adanya Kelompok usaha bersama, menjadi salah satu upaya yang dapat meningkatkan kesejahteraan Keluarga, pemberdayaan keluarga petani rumput laut melalui kelompok usaha bersama dapat membatu keluarga petani rumput laut dalam mencapai tingkat kesejahteraan, dapat kita ketahui kesejahteraan keluarga yakni terpenuhinya kebutuhan sosial, spritual masyarakat agar dapat mencapai fungsi sosialnya.

3. Hasil yang dicapai oleh masyarakat Desa Kolese Kecamatan Pasikolaga Kabupaten Muna dalam upaya peningkatan kesejahteraan kesejahteraan melalui budidaya rumput laut telah dapat teratasi dengan jalan membudidayakan rumput laut, dimana nilai hasi jualnya yang mencukupi, sehingga dapat membantu beban ekonomi masyarakat dan menjadikan kelaurga lebih sejahtera, meningkatkan pendapatan ekonomi, untuk biaya sekolah anak, meningkatkan kesejahteraan.

\section{DAFTAR PUSTAKA}

Adnan, A. (2012). Cognitive performance and dehydration. Journal of the American

College of Nutrition. 
Aliyudin, M. (2009). Pengembangan

Masyarakat Islam dalam Sistem

Dakwah Islamiyah dalam Ilmu

Dakwah: Academic Journal for

Homiletic Studies 4(16).

Andi Azhar Mustafa. 2015. Efektivitas

Program Kelompok Usaha Bersama

Fakir Miskin (Kube- Fm) Di Kota

Makassar: "Skripsi", Ilmu

Administrasi Negara Fakultas Ilmu

Sosial Dan Ilmu Politik Universitas

Hasanuddin Makassar.

Gianjar Kartasasmita, Pembangunan untuk Rakyat, (Jakarta: PT. Pustaka Cides, 1996)

Nurcholis, Hanif, 2011. "Pertumbuhan \& Penyelenggaraan Pemerintahan Desa", Penerbit Erlangga.

Usman Yatim dan Enny A Hendargo, Zakat dan Pajak, ( Jakarta: PT. Bina Rena Parieara, 1992) 